\title{
Biocontamination in Metal Traces (Pb, Cd) of Waters, Sediments and Fish from Urban and Periurban Marine Perimeters in the Community of Lokossa in Benin
}

\section{Armelle Sabine Yélignan Hounkpatin 1,2, Menouwesso Harold Hounhouigan ${ }^{3}$, Laura Loko4, Faustin Assongba ${ }^{4}$, Eric Bio Nikki Sare ${ }^{5}$}

${ }^{1}$ Interfaculty Center for Training and Research in Environment for Sustainable Development (CIFRED), University of Abomey-Calavi, Abomey-Calavi, Benin

${ }^{2}$ Technical Higher Teacher Training School (ENSET), National University of Sciences, Technologies, Engineering and Mathematics (UNSTIM), Abomey, Benin

${ }^{3}$ School of Sciences and Techniques for Conservation and Processing of Agricultural Products, National University of Agriculture, Ketou, Benin

${ }^{4}$ Faculty of Sciences and Technology, National University of Sciences, Technologies, Engineering and Mathematics (UNSTIM), Abomey, Benin

${ }^{5}$ Inter-Regional University of Industrial Engineering, Biotechnologies and Applied Sciences (IRGIB-Africa), Cotonou, Benin Email: harmelle2011@gmail.com

How to cite this paper: Hounkpatin, A.S.Y., Hounhouigan, M.H., Loko, L., Assongba, F. and Sare, E.B.N. (2021) Biocontamination in Metal Traces $(\mathrm{Pb}, \mathrm{Cd})$ of Waters, Sediments and Fish from Urban and Periurban Marine Perimeters in the Community of Lokossa in Benin. Journal of Agricultural Chemistry and Environment, 10, 436-446. https://doi.org/10.4236/jacen.2021.104029

Received: September 29, 2021

Accepted: November 1, 2021

Published: November 4, 2021

Copyright (c) 2021 by author(s) and Scientific Research Publishing Inc. This work is licensed under the Creative Commons Attribution International License (CC BY 4.0).

http://creativecommons.org/licenses/by/4.0/ (c) (i) Open Access

\begin{abstract}
In Benin, market gardening has become a new profession and plays an important role in the supply of fresh vegetables. In the coastal regions, fish farming is practiced on the outskirts of market gardening sites. However, poorly regulated cultivation practices and increasing pollution do not necessarily guarantee the sanitary quality of the products delivered. This study aims to evaluate the physico-chemical qualities of the water used for watering and, secondly, the lead and cadmium contamination of the water used for watering, the soil (sediment) and the fish products (fish) on the urban market gardening perimeter in the commune of Lokossa in Benin. These various samples taken for this purpose were analysed at the Ministry of Health's Water and Food Quality Control Laboratory. We noted pollution of organic elements through the physico-chemical parameters measured such as temperature, NTK, COD, BOD and total phosphorus and confirmed by average lead and cadmium levels of $0.42 \mathrm{mg} / \mathrm{L}$ in water, $0.52 \mathrm{mg} / \mathrm{L}$ in sediment and 0.31 $\mathrm{mg} / \mathrm{L}$ to $0.76 \mathrm{mg} / \mathrm{L}$ in fish tissue (Carp and Catfish) for lead and $0.07 \mathrm{mg} / \mathrm{L}$ in water, $0.1 \mathrm{mg} / \mathrm{L}$ in sediment and $0.5 \mathrm{mg} / \mathrm{L}$ in fish for cadmium. These rates are well above the normal values accepted by the GESAMP, PNEC INERIS
\end{abstract}


and FAO standards. The consequences of this contamination are health risks for consumers.

\section{Keywords}

Fish, Soil, Water, Lead, Cadmium, Lokossa

\section{Introduction}

In sub-Saharan Africa, it is estimated that $10 \%$ of the urban population uses wastewater for crop irrigation, with $50 \%-90 \%$ of urban dwellers in West Africa having already consumed vegetables irrigated with wastewater or polluted surface water [1]. Urban and peri-urban market gardening practiced in coastal areas plays an important role in the supply of vegetables to cities with growing populations in developing countries south of the Sahara [2].

However, contrary to the seasonal production of food crops in the countryside, market gardening in urban areas is practiced all year round with intensive production techniques that do not guarantee the sanitary quality of the vegetables produced [3]. This intensive agriculture is very dynamic, but it is not without [4]. Indeed, the uncontrolled and high quantity use of agricultural inputs and pesticides leads to environmental and public health problems which generate other economic constraints linked to the high cost of production [5]. Several lakes in Benin are polluted with heavy metals that accumulate in water, sediments, fish products and market gardening products. This is not without consequences for the health of consumers [6] [7].

This study, entitled "bio-contamination of water, soil and fish products in urban and peri-urban market gardening perimeters in the commune of Lokossa in Benin with trace metal elements $(\mathrm{Pb}, \mathrm{Cd})$, aims to assess the level of pollution and heavy metal contamination of the various components, i.e. irrigation water, soil and fish, in urban market gardening perimeters in the commune of Lokossa in Benin.

\section{Materials and Methods}

\subsection{Study Framework}

Located in the Department of Mono, on the Atlantic coast, the Municipality of Lokossa (Figure 1) is between $6^{\circ} 34^{\prime} 52^{\prime \prime}$ and $6^{\circ} 44^{\prime} 25^{\prime \prime}$ North latitude and between $1^{\circ} 36^{\prime} 46^{\prime \prime}$ and $1^{\circ} 52^{\prime} 17^{\prime \prime}$ East longitude and covers an area of $260 \mathrm{~km}^{2}$ with a population of 109,839 inhabitants divided into five districts. Like the entire coastal region, it enjoys a sub-equatorial climate, characterised by slight temperature variations (annual average of $27.4^{\circ} \mathrm{C}$ ) and bimodal rainfall: 1) a long dry season from November to April, 2) a long rainy season from April to July, 3) a short dry season from August to September, 4) a short rainy season from September to October. The average annual rainfall is $882.1 \mathrm{~mm}$ [8]. 


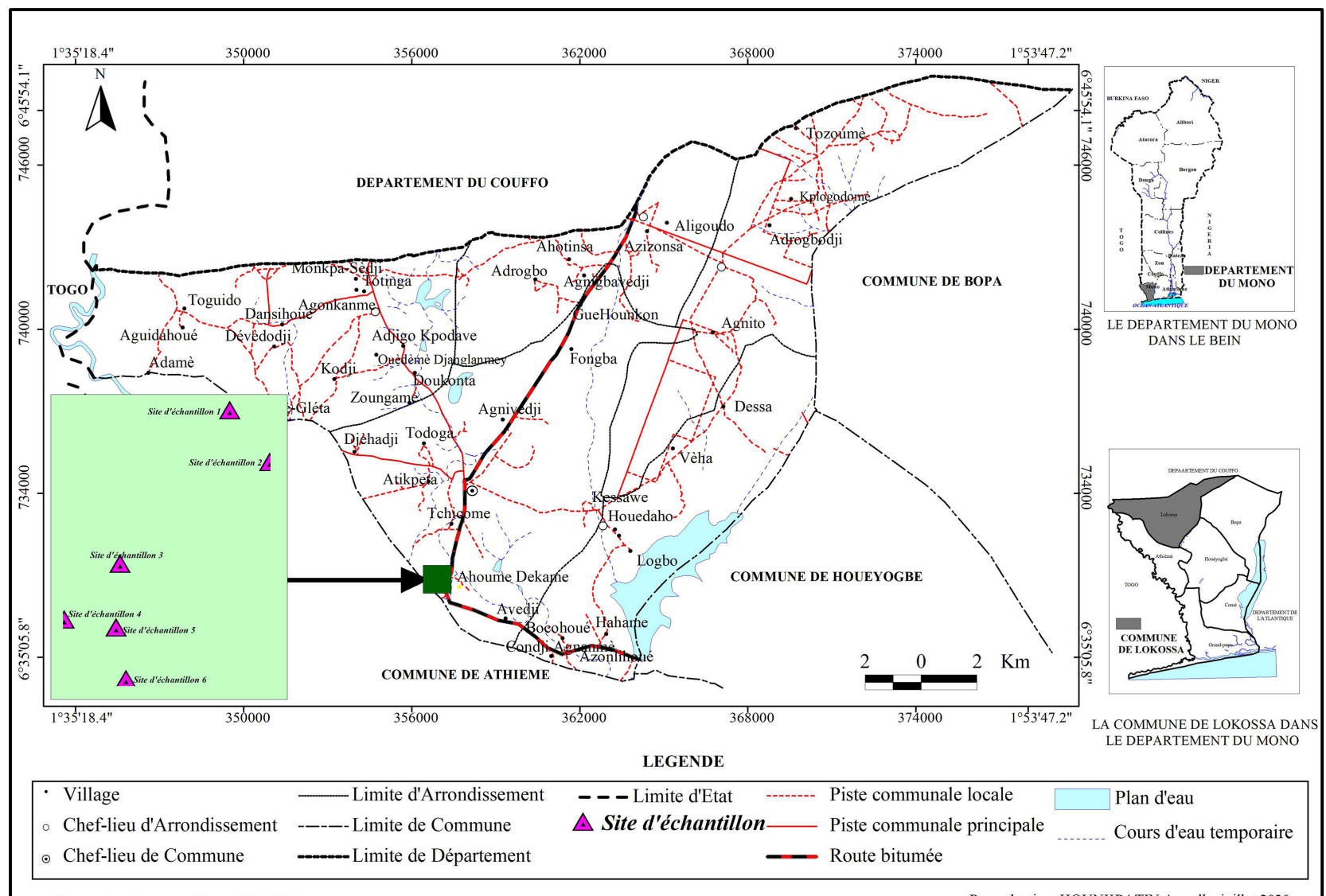

Source: Fond topographique IGN, 1992

Reproduction: HOUNKPATIN Armelle, juillet 2020

Figure 1. Geographical location of the study area.

\subsection{Sampling}

This study is a cross-cutting descriptive and analytical study carried out at the level of the Ahoume Dekame market gardening perimeter in Benin in 2019. Sampling focused on: water used for irrigation and fish farming, sediments and then fish; the most produced and the most consumed.

Water samples are taken at six (06) sites that are points on the waterways most used by market gardeners and fish farmers. The samples were taken using a two-liters bottle encrusted in a wooden cage that was made of confessional wood for the occasion. The cage is hang up down by two rocky masses that are attached to the side of the cage. The bottle has a polystyrene stopper to which is attached a thread that has been pulled to uncork it (a knot is tied every meter to assess the depth of immersion); the bottle is removed from the water when it is filled. The water collected was stored in a cool place at about $04^{\circ} \mathrm{C}$ in a cooler prepared for the occasion. A total of 6 water samples were taken.

Sediment samples were taken from $0-20 \mathrm{~cm}$ horizons in the root zone of the crops, and from the bottom of the fish ponds. Twelve (12) samples were taken. The soils were collected per site using a Beckmann bucket. Once collected, the soil is poured into sterile flasks and placed in a cooler.

The most popular fresh fish such as carp and catfish were targeted and caught 
with the help of sinners and market gardening producers. At this level, a total of twelve (12) samples were taken and kept in labelled sterile bags. Only those fish deemed fit for consumption were sampled at the randomly selected ponds for each species.

A total of 30 samples were taken as follows: 6 water samples, 12 sediment samples, 12 fresh fish samples stored in a cooler from the accumulator to the laboratory.

\subsection{Laboratory Analysis}

The methods used for the analyses are those of mineralisation of the samples according to $\mathrm{HACH}$ (Water Quality Testing and Analytical Instruments) and those of determination with the Molecular Absorption Spectrophotometer (DR 3900) by Dithizone methods for the determination of lead and cadmium. The analyses were carried out at the Water and Food Quality Control Laboratory (LCQEA) of the Ministry of Public Health in Benin.

\subsection{Statistical Analysis of the Data}

All data have been subject to statistical processing. The software used is SPSS, version 17.0. The software Epi info, Excel 2016, the regulatory standards used are those set by GESAMP (1982) for water, the PNEC INERIS standard for soils and by the WHO (2001) for market garden products. The compliance tests were carried out with the Student test at the 5\% threshold.

\section{Results}

\subsection{Evaluation of the Physico-Chemical Parameters of the Irrigation Water}

Table 1 below shows the results of the physico-chemical parameters dosed into the irrigation water.

\subsection{Assessment of the Lead and Cadmium Content in Vegetable Irrigation Water}

Figure 2 shows the lead and cadmium levels in irrigation water.

Table 1. Results of the physico-chemical parameters of the irrigation water.

\begin{tabular}{|c|c|c|c|c|c|}
\hline & $\begin{array}{l}\mathrm{T} \\
{ }^{\circ} \mathrm{C}\end{array}$ & $\begin{array}{l}\mathrm{NTK} \\
\mathrm{mg} / \mathrm{L}\end{array}$ & $\begin{array}{l}\text { Total Phosphorus } \\
\text { (P-PO43-) mg/L }\end{array}$ & $\begin{array}{c}\mathrm{COD} \\
\mathrm{mg} / \mathrm{L} \text { of } \mathrm{O}_{2}\end{array}$ & $\begin{array}{c}\text { BOD520 } \\
\mathrm{mg} / \mathrm{L} \text { of } \mathrm{O}_{2}\end{array}$ \\
\hline Water 1 & 26.2 & 3.08 & 8.94 & 61.21 & 22 \\
\hline Water 2 & 26.2 & 4.18 & 3.01 & 53.56 & 17 \\
\hline Water 3 & 27.1 & 3.11 & 6.32 & 91.82 & 23 \\
\hline Water 4 & 26.9 & 3.78 & 3.58 & 156.85 & 19 \\
\hline Water 5 & 26.9 & 2.32 & 0.46 & 118.6 & 27 \\
\hline Water 6 & 27.1 & 4.80 & 3.43 & 107.12 & 25 \\
\hline Average & - & 3.54 & 5.005 & 114.55 & 22.16 \\
\hline
\end{tabular}




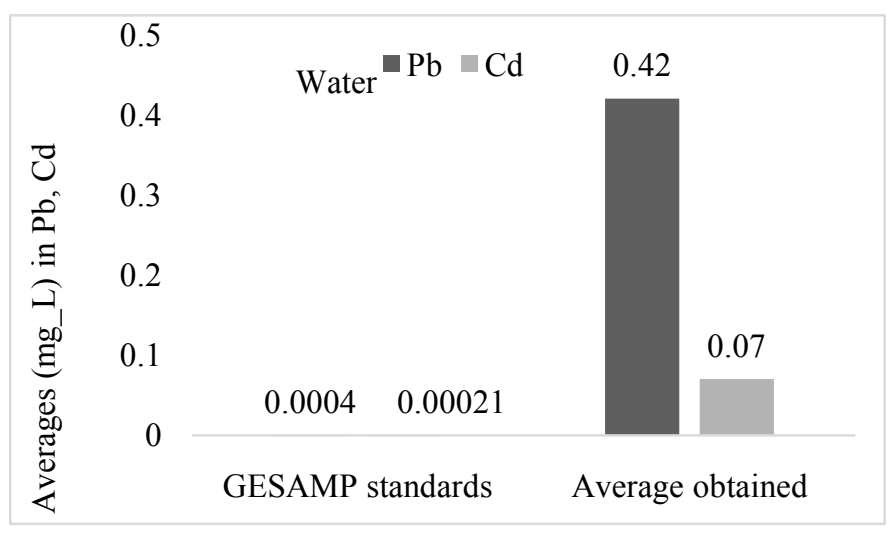

Figure 2. Average content $(\mathrm{mg} / \mathrm{L})$ of $\mathrm{MTE}(\mathrm{Pb}, \mathrm{Cd})$ in vegetable irrigation water.

From the analysis of this Figure 2, it can be seen that the average levels obtained in the irrigation water of Lead $(0.42 \mathrm{mg} / \mathrm{L})$ and Cadmium $(0.07 \mathrm{mg} / \mathrm{L})$ exceed all the regulatory standards set by GESAMP for these metals: $\mathrm{Pb}(0.0004$ $\mathrm{mg} / \mathrm{L}) ; \mathrm{Cd}(0.00021 \mathrm{mg} / \mathrm{L})$. It can be deduced that the water used to irrigate crops is contaminated with Lead and Cadmium.

\subsection{Assessment of Lead and Cadmium Content in Soil (Sediment)}

Figure 3 shows the lead and cadmium levels in soils samples.

From the analysis of Figure 3, it can be seen that the soils are not contaminated by either Lead or Cadmium, as the averages obtained are all below the regulatory standard required by PNEC INERIS: $\mathrm{Pb}(19 \mathrm{mg} / \mathrm{kg})$; $\mathrm{Cd}(12 \mathrm{mg} / \mathrm{kg})$ for soils.

\subsection{Assessment of Lead and Cadmium Content in Fish}

Figure 4 shows the level of lead and cadmium contamination in fish.

From the analysis of the data in Figure 4, we see an accumulation of lead and cadmium in the tissues of both types of sampled fish. Lead is more accumulated in fish than cadmium, at $0.5374 \mathrm{mg} / \mathrm{L}(\mathrm{Pb})$ and $0.05 \mathrm{mg} / \mathrm{L}(\mathrm{Cd})$ compared to 0.30 $\mathrm{mg} / \mathrm{L}$ for Lead and $0.05 \mathrm{mg} / \mathrm{L}$ for Cadmium allowed by the standards. A comparative analysis allows us to note that the silurid (catfish) species accumulates more lead (with an average of $0.76 \mathrm{mg} / \mathrm{L}$ ) than the carps species (whose average is $0.31 \mathrm{mg} / \mathrm{L}$ ). However, the average cadmium values for both species are close to the norm.

\subsection{Correlation of Chemical Elements $(\mathrm{Pb}, \mathrm{Cd})$ and Sampled Components (Water, Sediment and Fish)}

Figure 5 below shows the correlation between the dosed chemical elements and the sampled components.

This graph illustrates that lead and cadmium are more concentrated in the sediment than in the other components, namely water and fish, with values of 19 $\mathrm{mg} / \mathrm{L}$ and $12 \mathrm{mg} / \mathrm{L}$ respectively. 


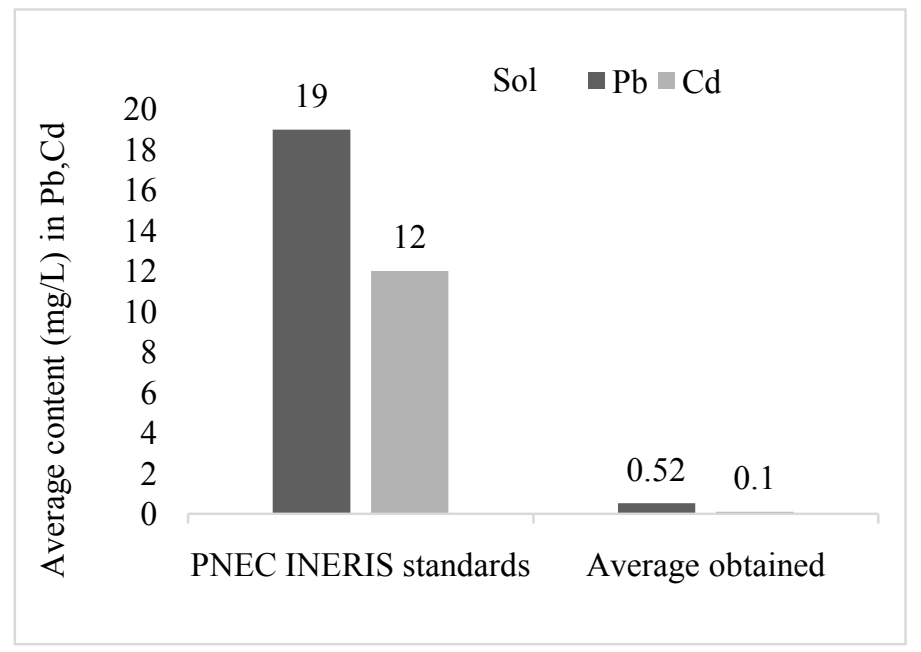

Figure 3. Average content (mg/L) of MTE (Pb, Cd) in soils.

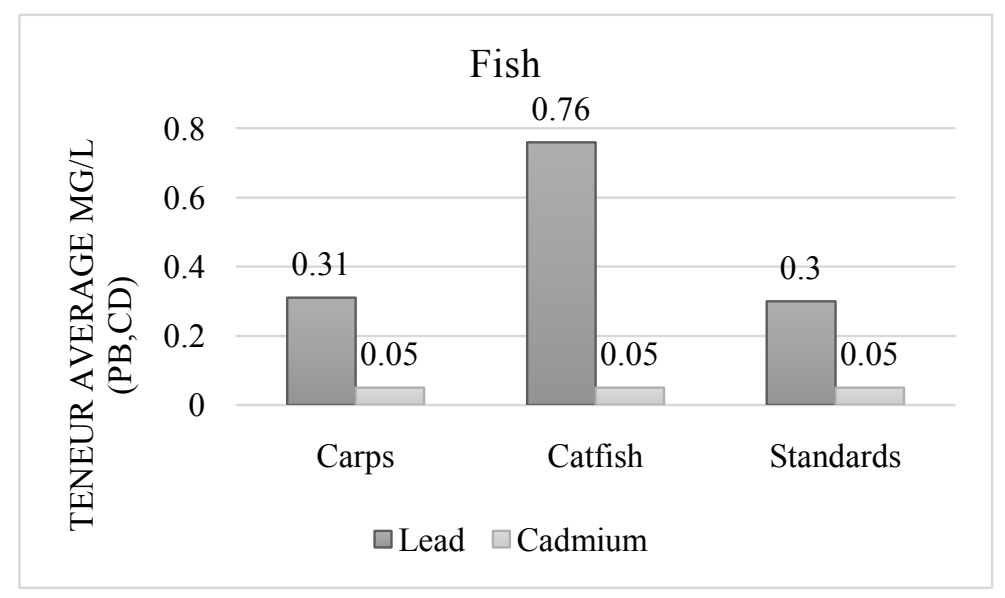

Figure 4. Average content (mg/L) of TMEs $(\mathrm{Pb}, \mathrm{Cd})$ in fish.

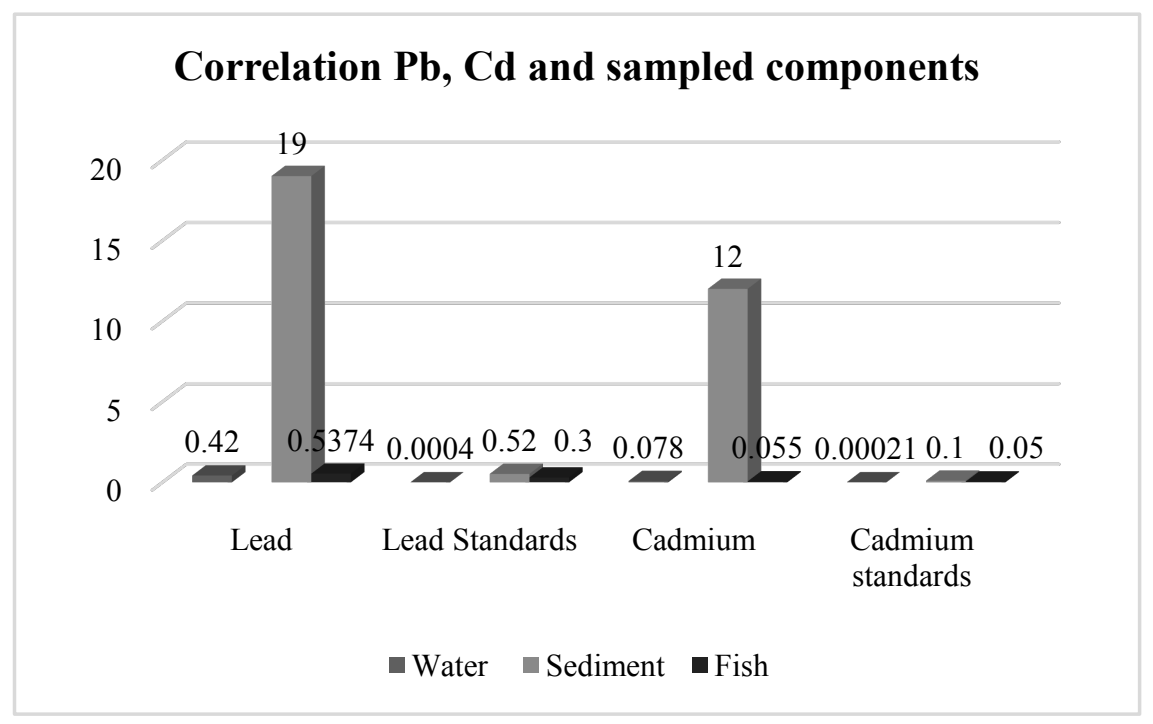

Figure 5. Correlation between chemical elements $(\mathrm{Pb}, \mathrm{Cd})$ and sampled components (water, sediment and fish). 


\section{Discussion}

Urban agriculture is an alternative for the availability of fresh produce at any season of the year. In Benin, in the coastal zone, this agriculture focused on market gardening is sometimes associated with fishing activities, particularly fish farming. At the level of the market gardening perimeter of the commune of Lokossa where our study was carried out, the different parameters measured confirmed a contamination in chemical elements of several components such as irrigation water, sediments, fish, all sampled at the site level.

Concerning the physico-chemical parameters evaluated, the temperature varies between $26.2^{\circ} \mathrm{C}$ and $27.1^{\circ} \mathrm{C}$. This difference in temperature can be explained by the sunshine, the season, the level of contamination and pollution and then by the water source. Djegbe et al. (2018) found similar results with a temperature difference of up to $34.04^{\circ} \mathrm{C}$. The determination of chemical and organic indicators of water pollution such as NTK (Total Nitrogen Kjeldahl), Total Phosphorus, COD (Chemical Oxygen Demand) and BOD (Biological Oxygen Demand), whose respective average values are $3.54 \mathrm{mg} / \mathrm{L} ; 5.005 \mathrm{mg} / \mathrm{L} ; 114.55 \mathrm{mg} / \mathrm{L}$ and $22.16 \mathrm{mg} / \mathrm{L}$, indicate chemical contamination of these irrigation waters with organic elements and could also, at the same time, favour the proliferation of microbiological contaminants. In the same sense, the results of the work of [9] indicate a strong mineralisation due to a richness in minerals of various wastes from anthropic activities and also to the concentration of these minerals resulting from the evaporation of part of the water in the dry season with TDS that allow the quantity of dissolved matter of elements such as calcium, magnesium, sodium, chlorides and sulphates to be known [10]. In addition to the physicochemical parameters taken into account by our study, [11] confirm nitrate contamination of the waters of the Houéyiho market garden perimeter (Cotonou). These physico-chemical parameters led us to the dosage and confirmation of chemical contaminants in these waters.

In the water used for watering this market garden perimeter, we note that the lead concentration significantly exceeds that allowed by the regulations, i.e. the GESAMP standard, with a difference of around 0.0416, i.e. 1000 times more; this could be due to an anthropic origin which can be explained by all the human activities carried out around the water points which are not only used by the market gardeners but also by other people for various purposes given their location in urban and peri-urban areas where other activities are carried out. These results are in line with those of [11] who indicated that, apart from market gardening and soil, the irrigation water of the market gardening site of Houéyiho (Cotonou) in the Republic of Benin is contaminated not only by heavy metals but also by nitrates. The same is true for cadmium, which is always present in the irrigation water and whose average values are much higher than those recommended. Both cadmium and lead are trace metal elements that are easily found in surface water and in pits in urban areas. They are drained into these reservoirs by rainwater runoff and come mainly from the various human activi- 
ties carried out in urban areas, namely: household waste dumps; the combustion of petroleum products; and the combustion of coal, which partly explain this contamination.

In the sediments, our results indicate the presence of lead and cadmium with average values below the accepted standards. This could be explained either by a professional awareness of the adoption of new cultivation practices or by a great infiltration of these chemical elements much deeper and or a non-homogeneity of the compost used during the formation of the beds. Several authors have detected the presence of these heavy metals in soils and sediments in market gardening environments with varying concentrations depending on the site and the type of fertilizer used. This is the case of [12] which confirms a strong contamination of soils in the urban market gardening perimeter of Yaoundé in Cameroon. According to studies by [13], which are in line with ours, in droppings and composts only the iron concentration exceeds standards and the other elements $\mathrm{Pb}$ and $\mathrm{Cd}$ are in acceptable concentrations. According to [14], while some of the heavy metals go directly to soil and water, most of them are first emitted to the atmosphere before joining the other two elements. We found a high concentration of heavy metals in sediments more than in the other sampled components (water and fish), the same finding was made by [6] with a slight difference for cadmium.

In fish products, especially two species of fish: carp and catfish, we have detected the presence of Lead and Cadmium which remain concentrated in the muscles of these fish. This contamination is certainly due to the use of the water from the market garden site which, according to our previous studies, is highly contaminated by lead and cadmium. Given that fish farming is directly associated with market gardening on this site, we can assert a cross-contamination which can be explained by the use of the components (water, soil or sediment, crops...) by the fish farmers and the consumption of its components by the fish. In addition to this, the use of inadequate or recycled material, a probable source of heavy metals, the use of feed or fish food from local formulations. Our results corroborate those of [15] who, following a study carried out in the coastal region of Côte d'Ivoire, found that the organs of fish caught in these areas are more contaminated with heavy metals during the rainy and flood seasons because anthropic activities in the continental and maritime zones induce a high contamination of the organs. Similar results are obtained by [16] whose results of analyses carried out on the tissues of Nile tilapia fish and African catfish reveal the presence of heavy metals such as cadmium $(\mathrm{Cd})$, lead $(\mathrm{Pb})$, arsenic $(\mathrm{As})$, chromium $(\mathrm{Cr})$ and cobalt $(\mathrm{Co})$ he states that these metals are present in various proportions in the liver and muscle tissue of the two fish species studied and that the liver concentrates more metals than muscle tissue.

After a comparative analysis of the average levels, we found that the silurid species accumulates more lead (with an average of $0.76 \mathrm{mg} / \mathrm{L}$ ) than the carp species (with an average of $0.31 \mathrm{mg} / \mathrm{L}$ ). But the average cadmium values for both 
species are close to the norm. Our results are in line with those of [6] who found that lead and cadmium accumulation varies between fish species in the Ganvié lake region of Benin as well as those of [16] [17] who found that heavy metal levels are generally variable in fish, more specifically, higher in Nile Tilapia than African catfish and other species following their work in Lake Chad and market gardening sites in Burkina Faso respectively. Similar results have also been reported by [7] in the same commune at the level of Lake Loho, who reported the contamination not only of one fish species but also of water, sediments and some market garden products by heavy metals, namely lead, cadmium and arsenic, which presents toxicological risks.

In terms of public health, the consumption of such fishery products could be a source of several water-borne diseases (cholera, dysentery, etc.) or non-water-borne diseases that could adversely affect the health of consumers.

\section{Conclusion}

In short, this study has made it possible to evaluate the quality of the soil, water and fishery products of the market garden perimeter of the municipality of Lokossa. The results show that the concentrations of metallic trace elements $(\mathrm{Pb}$ and Cd) are high in the water and the fishery products (fish) in accordance with the norms and acceptable at the sediment level according to the indicated standard. This work is of great interest for the preservation of vegetable soil resources in urban and peri-urban areas. Appropriate measures are required for the effective and efficient treatment of waste water before use. In the same way, raising the awareness of market gardeners and local residents on the general hygiene to be adopted on the site is necessary to improve the quality of products in order to preserve the health of consumers, given the many sources of suspected contamination.

\section{Conflicts of Interest}

The authors declare no conflicts of interest regarding the publication of this paper.

\section{References}

[1] Malik, A.S., Boyko, O., Atkar, N. and Young, W.F. (2001) A Comparative Study of MR Imaging Profile of Titanium Pedicle Screws. Acta Radiologica, 42, 291-293. https://doi.org/10.1080/028418501127346846

[2] Amoah, I.D., Abubakari, A., Stenstrom, T.A., Abaidoo, R.C. and Seidu, R. (2016) Contribution of Wastewater Irrigation to Soil Transmitted Helminths Infection among Vegetable Farmers in Kumasi, Ghana. PLOS Neglected Tropical Diseases, 10, 1-12. https://doi.org/10.1371/journal.pntd.0005161

[3] Gnandi, K., Tozo, K., Edorh, A.P., Abi, H., Agbeko, K., Amouzouvi, K., Baba, G., Tchangbedji, G., Killi, K., Bouchet, P. and Akpagana, K. (2013) Bioaccumulation of Certain Metallic Elements in Market Garden Produce Grown on Urban Soils along the Lomé-Aného Motorway, South Togo. Acta Botanica Gallica, 155, 415-426. https://doi.org/10.1080/12538078.2008.10516121 
[4] Allagbe, H., Aitchedji, M. and Yadouleton, A. (2014) Genesis and Development of Urban Market Gardening in the Republic of Benin. International Journal of Innovation and Applied Studies, 7, 123-133. http://www.ijias.issr-journals.org/

[5] Agueh, V., Degbey, C.C., Sossa, J., Adomahou, D., Paraiso, M.N., Vissoh, S., Makoutode, M. and Fayomi, B. (2015) Niveau de contamination des produits maraîchers par les substances toxiques sur le site de Houéyiho au Bénin. International Journal of Biological and Chemical Sciences, 9, 542-551. https://doi.org/10.4314/ijbcs.v9i1.46 http://ajol.info/index.php/ijbcs

[6] Akogbeto, M., Djouaka, R. and Noukpo, H. (2005) Use of Agricultural Insecticides in Benin. Bulletin de la Société de Pathologie Exotique, 12, 400-405. https://agritrop.cirad.fr/572410/1/document_572410.pdf

[7] Hounkpatin, A.S., Edorh, A.P., Sèzonlin, M., Guédénon, P., Elégbédé, B., Boni, G., Dougnon, V., Montcho, S., Kéké, E. and Boko, M. (2012) Pollution of Aquatic Ecosystems by Heavy Metals at Ganvié's lacustrine city (Benin). International Research Journal of Biotechnology, 3, 81-87. http://www.interesjournals.org/IRJOB

[8] Hekpazo, P.M., Hounkpatin, A.S.Y., Dougnon, V.T., Boni, G., Pognon, E. and Johnson, R.C. (2020) Assessment of Metallic Contamination (Lead, Cadmium and Arsenic) and Toxicological Risk Analysis at Houin Logbo (Toho Lake) in the Commune of Lokossa in South-Western Benin. Bulletin de la Recherche Agronomique du Bénin (BRAB), 30, 54-64.

[9] Bamahossovi, C., Franco, N., Djessonou, S.C., Akindele, A.A. and Ogouwale, E. (2016) Effects of Climatic Risks on Food Production in the Commune of Lokossa (Benin). European Scientific Journal, 12, 370-379. https://doi.org/10.19044/esj.2016.v12n29p370

[10] Djegbe, I., Taïra, S., Tamou-Tabe, N., Topanou, F., Soglo, M., Paraiso, A., Djouaka, R. and Kelome, C.N. (2018). Variation saisonnière de la qualité physicochimique et microbiologique des eaux d'irrigation et des légumes du site maraîcher de Bawéra et risques sanitaires associés. International Journal of Biological and Chemical Sciences, 12, 781-795. https://doi.org/10.4314/ijbcs.v12i2.13

[11] Ndinwa, C.C.G., Chukumah, O.C., Edafe, E.A., Obarakpor, K.I., Morka, W. and Osubor-Ndinwa, P.N. (2012) Physio-Chemical and Bacteriological Characteristics of Bottled and Sachet Brand of Packaged Water in Warri and Abraka, Southern Nigeria. Journal of Environmental Management and Safety, 3, 145-160.

[12] Yehouenou, E., Soton, A., Azocli, A., Acakpo, H., Boco, M., Fourn, L., Houinsa N., Keke, J.C. and Fayomi, B. (2010) Contamination of Soil, Water and Market Garden Produce by Toxic Substances and Heavy Metals on the Houéyiho Site (Cotonou, Benin). International Journal of Biological and Chemical Sciences, 4, 2160-2168. https://doi.org/10.4314/ijbcs.v4i6.64951

[13] Nguelieu, C.R. (2017) Evaluation of the Risks of Contamination in Metallic Trace Elements ( $\mathrm{Pb}, \mathrm{Cd}, \mathrm{Zn}$ ) of Urban Market Gardening Sites in Yaoundé (Cameroon). Mémoire de Master, University of Liege, Liege, 37-39.

[14] Atidégla, S. (2011) Effects of Different Doses of Mineral Fertilisers and Poultry Droppings on the Accumulation of Biocontaminants and Pollutants (Faecal Germs, Nitrogen and Phosphorus Compounds, Heavy Metals) in the Waters, Soils and Vegetables of Grand-Popo in Benin. PhD Thesis, EDP/FLASH, University of Abomey-Calavi (UAC), Benin.

[15] Semde, I. (2005). Report on the "Contribution of Burkina Faso to the Study on Lead and Cadmium" Ministry of the Environment and Living Environment, General Directorate for the Improvement of the Living Environment, 26p.

[16] Kouamenan, N.M., Coulibaly, S., Atse, B.C. and Goore, B.G. (2020) Bioaccumulation 
des métaux lourds dans les tissus de deux espèces de Cichlide (Hemichromis fasciatus et Tilapia zillii $\times$ Tilapia guineensis) pêchés dans la lagune Ebrié, Côte d'Ivoire. Journal of Applied Biosciences, 148, 15218-15229. https://doi.org/10.35759/JABs.148.6

[17] Ouédraogo, A. (2016). Evaluation of the Heavy Metal Content in the Tissues of Nile Tilapia (Oreochromis liiloticus) and African Catfish (Clarias sp.) from Freshwater Burkina faso. Dissertation, Polytechnic University of Bobo-Dioulasso, Dindéresso. http://www.secheresse.info/spip.php?article71590 